\title{
Efektivitas Komunikasi Nonverbal Supeltas dalam Mengatur Lalu-lintas di Surakarta
}

\author{
Bedjo Sukarno
}

\begin{abstract}
Traffic control volunteer worker motivation objective indirectly want to create traffic road conditions are not always jammed, but they were able to unravel for smooth for all road users with communication devices owned that body language and whistles. Nonverbal messages such as body language, which refers to an object used consistently by its users. Appearance and style of volunteers who served in front of the highway users make sense of something that is consistent because it pollutes the material that has been prevailing in the society. That's when the process of formation of meaning in the minds of the road users in general.

Keywords: Volunteer Officers Motive, Credibility Evective Volunteer Officers and nonverbal messages.
\end{abstract}

\section{A. Pendahuluan}

Kondisi di lapangan menunjukkan bahwa keadaan lalulintas di berbagai sudut jalan baik di pinggiran kota maupun di tengah kota itu sendiri akhir-akhir ini di kota Surakarta mengalami kemacetan ketika pagi hari maupun sore hari bersamaan waktu atau jam kantor pulang kerja. Pemerintah mempunyai tujuan untuk mewujudkan lalulintas dan angkutan jalan yang selamat, aman, cepat, lancar, tertib dan teratur, nyaman dan efisien melalui manajemen lalulintas dan rekayasa lalulintas.

Munculnya sukarelawan lalulintas dadakan di pertigaan, perempatan, ataupun tiap sudut jalan lalulintas maupun di penyeberangan/zebra cross adalah terlihat secara ikhlas bermaksud untuk membantu mengatur lalulintas dan membantu pejalan kaki yang sedang menyeberangi jalan lalulintas agar semua pengguna jalan segera sampai pada lokasi tujuan tepat waktu. Di sisi lain, jumlah personil aparat petugas lalulintas dari kepolisian dan Dinas Perhubungan sangat terbatas untuk mengatur atau melayani publik di tengah masyarakat pengguna jalan lalulintas sehingga terjadi kemacetan di berbagai pertigaan atau perempatan jalan yang belum dilengkapi lampu traffic light khususnya di Surakarta. Bagi sukarelawan lalulintas atau supeltas merupakan sebuah tantangan yang cukup berat dalam menghadapi resiko yang mungkin akan diterimanya, dengan hadirnya mereka petugas dadakan lalulintas di tengah kesibukan yang kompleks dan padat oleh pemakai jalan lalulintas tepatnya di pertigaan atau perempatan sangat berfungsi dalam mengatur menjadi lebih lancar dan tertib.

Dari sudut pandang teknik berkomunikasi, bahwa kita sering berpendapat bahasa lisan dan tertulis sebagai medium utama komunikasi, tetapi pesan yang disampaikan dan yang diterima amat dipengaruhi oleh faktor nonverbal seperti gerakan tubuh, penampilan 
dalam berpakaian, jarak berdiri ketika diantara kedua orang yang sedang berbicara, postur tubuh, gerakan anggota badan, ekspresi wajah, gerakan mata maupun sentuhan badan. Seperti halnya suatu pesan yang amat sederhana menanyakan tentang keadaan kesehatan seseorang, dapat disampaikan dengan cara atau maksud berbeda-beda dalam bentuk komunikasi nonverbal (Alexandra Sindoro, 1996: 221). Mungkin dalam menjawab salam tersebut tanpa mengangkat wajahnya tapi cukup dengan acungan ibu jarinya.

Komunikasi nonverbal mempunyai pengaruh besar dalam memberikan makna dan harus selaras dengan pesan verbal. Dalam menganalisis komunikasi nonverbal dari orang lain dan menerapkan apa yang dipelajari pada diri sendiri serta ketika berhubungan dengan orang lain adalah bermanfaat. Oleh karena itu, yang dilakukan oleh supeltas merupakan cara-cara yang secara tidak disadari dengan menggunakan lambang komunikasi gerak tubuhnya atau bahasa tubuh sebagai medium berkomunikasi untuk mengatur masyarakat pengguna jalan cukup menarik dan komunikatif untuk diteliti. Bagamainakah efektivitas komunikasi nonverbal Supeltas dalam mengatur lalulintas di berbagai ruas jalan di Surakarta?

Luaran penelitian yang ingin dicapai dari hasil penelitian ini adalah tehnik komunikasi yang diaplikasikan lewat lambang atau pesan nonverbal oleh Supeltas sebagai komuniktor ketika mempengruhi dan mengatur publik dalam situasi tertentu yang dilakukan untuk mengatasi masalah keruwetan di ruas jalan lalulintas wilayah Surakarta. Memberikan pengetahuan secara umum mengenai sikap dan perilaku yang ditampilkan seorang warga biasa dalam pengabdiannya tanpa pamrih, dan sangat bermanfaat bagi masyarakat umum sebagai contoh tauladan dalam mengamalkanya untuk kepentingan umum. Tingkat kepercayaan pekerja relawan lalulintas yang secara tidak langsung sangat diapresiasi oleh banyak pengguna jalan lalulintas.

Penelitian ini mengharap akan menemukan pengetahuan baru secara konkrit tentang ketrampilan dan gaya penampilan kreatif dalam berkomunikasi yang efektif dihadapan khalayak. Juga mampu dalam mengendalikan bermacam bentuk tanggapan dengan menggunakan lambang komunikasi nonverbal yang tepat. Disamping hal tersebut, juga dimaksudkan sebagai upaya mengetahui tingkat kredibilitas Supeltas selaku komunikator yang secara tidak langsung mempunyai pengaruh dalam mengatur permasalahan yang sedang terjadi di masyarakat.

\section{B. Metode Penelitian}

\section{Jenis Penelitian}

Dalam penelitian ini peneliti menggunakan informan sebagai sumber dalam memperoleh data untuk penelitian ini. Pemilihan informan didasarkan pada subjek yang banyak memiliki informasi yang berkualitas dengan permasalahan yang diteliti dan bersedia memberikan data. Maka pendekatan penelitian yang hendak dilakukan menggunakan pendekatan kualitatif. Menurut Hamidi (2007:5) informan adalah orang yang dapat memberi informasi tentang dirinya dan orang lain. Informan yang banyak mengetahui tentang kondisi dan situasi objek yang diteliti. 
Diterbitkan oleh Program Studi IImu Komunikasi

Universitas Ahmad Dahlan Yogyakarta

Peneliti memilih informan berdasarkan beberapa pertimbangan yaitu informan yang dipilih peneliti adalah orang dianggap paling tahu dan menguasai tentang apa yang peneliti ingin teliti. Pengambilan informan dengan cara ini dapat disebut pula dengan cara purposive sampling (Sugiyono, 2009:216).

Namun dlm penelitian ini dilakukan modifikasi dengan obyek dan metode interaktif yang digunakan dng tinjauan pustaka dan beberapa teori yang ada, maka peneliti mengajukan kerangka pemikiran yg menggambarkan pelaksanaan komunikasi melalui nonverbal dalam mengatur kemacetan lalulintas di pertigaan dan perempatan wilayah Surakarta

\section{Sumber Data}

Informasi yang paling penting untuk dikumpulkan dan dikaji dalam penelitian ini berupa data kualitatif. Informasi tersebut akan digali dari pelaku pekerja relawan dan pengguna jalan lalulintas di pertigaan dan perempatan yang dilalui pengendara bermotor.

\section{Teknik Pengumpulan Data}

a. Wawancara mendalam, jenis ini bersifat terbuka dan bisa dilakukan berulang pada informan yang sama. Teknik wawancara ini akan dilakukan pada semua informan.

b. Obsevasi, dalam observasi ini peneliti hanya sebagai pengamat yang hadir di lokasi.

c. Dokumentasi, merupakan teknik pengumpulan data dengan maksud mencatat langsung fenomena yang terlihat di lokasi, dan informasi yang ditemukan merupakan bahan pendukung hasil wawancara yang terkumpul.

\section{Teknik Analisa}

Dalam model analisis ini, reduksi data, sajian data dan penarikan simpulan atau verifikasinya, aktivitasnya dilakukan dalam bentuk interaktif dengan proses pengumpulan data sebagai suatu proses siklus. Aktivitas dalam bentuk interaktif tersebut baik pada analisis setiap unit kasusnya, maupun pada analisa antar kasusnya untuk memahami keesamaan dan perbedaannya. Dalam melaksanakan proses ini peneliti tetap selalu melakukan komponen analisis dengan pengumpulan datanya selama proses berlangsung.

Selanjutnya, peneliti hanya bergerak diantara tiga komponen analisis tersebut sesudah pengumpulan data selesai pada setiap unitnya dengan menggunakan waktu yang masih tersisa dalam penelitian ini. Apabila dalam proses mendekati simpulan akhir dirasakan belum cukup mantap, maka peneliti tetap akan berusaha kembali ke lokasi menggali data secara lebih fokus dengan tujuan mendapatkan data pendukung sebagai pelengkap dan pengembangan simpulan akhir, juga sebagai usaha bagi pendalaman data sebelum laporan dipastikan untuk disusun. (HB. Sutopo, 2006: 120) 


\section{Hasil Penelitian}

\section{Diskripsi Lokasi}

a. Keadaan dan Situasi Jalan Lalulintas Kota Solo

Pemkot Solo masih dihadapkan pada persoalan kemacetan lalulintas yang terjadi di hampir semua sudut pertigaan, perempatan jalan lalulintas yang belum tersedia traffic light setiap harinya selalu mengalami kemacetan. Banyak faktor yang menyebabkan kemacetan lalulintas seperti salah satu halnya anak pelajar tingkat SLTA dan kesibukan warga bagi mereka yang melakukan aktivitas masuk kerja dan pulang kerja maupun dalam kegiatan lain. Dengan berkembangnya pembangunan perumahan di berbagai tempat sekitar wilayah Solo raya juga berpengaruh pada penggunaan jalan raya, disebabkan dengan melajunya perkembangan teknologi dan perekonomian semua warga sudah hampir menyeluruh telah memiliki kendaraan bermotor.

Fasilitas transportasi yang sudah tersedia dari pemerintah sudah terpenuhi untuk melayani kebutuhan kegiatan warga dalam bekerja atau kesibukan yang lain, akan tetapi belum diberikan jalur lalulitas khusus untuk bis kota itu sendiri. Sehingga Batik Solo Transformasi selama ini masih menggunakan jalur lalulintas bersamaan dengan pengendara dan pengguna jalan yang lain, hal ini juga berakibat pada kemampuan jalan lalulintas yang berdesakan. Sedangkan kondisi fisik jalan raya belum ada perkembangan yang signifikan untuk memenuhi kebutuhan warga yang cukup padat bagi pengguna jalan raya secara umum.

Perlengkapan atau fasilitas traffic light jalan lalulitas keberadaannya masih terbatas di lokasi pertigaan atau perempatan yang lokasi kriterianya luas atau besar. Kemudian petugas aparat yang diterjunkan di lapangan nampak perbandingannya belum sesuai dengan jumlah pemakai pengendara motor dan mobil. Karena itu, berakibat juga pada kondisi jalan raya semakin kompleks dan pengendara motor itu sendiri sering berinisiatif melanggar ketertiban dan menggunakan jalan pintas, mungkin dengan alasan memburu waktu untuk segera sampai tujuan.

Dengan fenomena tersebut merupakan indikator yang menunjukkan adanya ketidak seimbangan antara jumlah pengguna jalan bermotor dan pengendara lain dengan sarana dan prasarana termasuk petugas lalulintas belum sepadan. Artinya, perlu pemikiran yang lebih detail lagi dalam rangka melayani serta memberikan antisipasi persoalanpersoalan yang terjadi keruwetan dan guna mengatur lalulintas di Kota Solo. Seperti terlihat di lapangan petugas lalulintas baik dari kepolisian lalulintas maupun dari Dinas Perhubungan meskipun sudah melaksanakan tugasnya masalah kemacetan masih saja dihadapi oleh mereka

Gambaran fenomena persoalan transportasi dan situasi serta kondisi jalan raya lalulintas di Kota Surakarta tersebut nampaknya menimbulkan perhatian khusus bagi kita semua sebagai warga Solo pengguna jalan lalulintas. Sehingga di tengah jalan raya baik di pertigaan atau diperempatan maupun di simpang jalan raya besar muncul keberadaan tenaga sukarelawan dari warga untuk mencoba membantu keruwetan yang berakibat kemacetan di jalan lalulintas, dan terlihat menunjukkan penuh keikhlasannya. Bagi masyarakat dengan keberadaan supeltas dalam membantu pengguna jalan lalilintas tersebut 
Diterbitkan oleh Program Studi IImu Komunikasi

Universitas Ahmad Dahlan Yogyakarta

sebenarnya merupakan salah satu jalan keluar untuk menertibkan kelancaran pengguna jalan.

Posisi supeltas sebagai petugas sukarelawan dengan identitas lengkap yang berwarna hijau skotlite berupa baju rompi tentunya sudah mendapatkatkan ijin resmi dari pihak aparat pemerintah yang terkait. Untuk itu, dari pihak aparat diharapkan memberikan bimbingan teknis dalam menjalankan tugas supeltas sehingga secara tidak langsung mereka mampu melakukan pekerjaan dengan baik dan akan memberikan persepsi positif dari masyarakat. Pihak Dinas Perhubungan dan kepolisian hendaknya proaktif dan selalu memperhatikan aktifitas supeltas ketika sedang melaksanakan kegiatannya di tengah jalan dan tidak semata-mata melepaskan begitu saja, mungkin akan berpengaruh atau mengganggu, bahkan juga bisa dikatakan membantu kepada tugas rutin aparat.

Batik Solo Trans (Bis Kota) dan angkutan umum yang memiliki ijin operasional di Kota Solo yang mempunyai koridor jalur lalulintas yang sangat teratur ternyata bukan merupakan satu-satunya pilihan utama sebagai sarana transportasi warga. Sebab dengan kondisi lalulintas sekarang ini di Kota Solo bagi warga jika dengan menggunakan transportasi umum mempunyai alasan tidak cukup waktu dalam perjalanan menuju tempat kerjanya dan mungkin sering mengalami keterlambatan. Disamping terjadi kemacetan dan pelayanannya dari pihak BST atau angkutan umum kurang mempertimbangkan keperluan atau kebutuhan waktu yang tepat bagi penumpang, tetapi lebih mengutamakan menunggu penumpang baru di tempat halte tertentu. Sehingga bisa dilihat kondisi realitas penumpang pengguna transportasi umum tidak lagi terjadi berjubelan karena berkurang peminatnya.

\section{b. Keberadaan Supeltas di Kota Solo}

Keberadaan Supeltas di Kota Solo relative terkoordinasi dengan baik, kegiatan tersebut informasinya bisa diperoleh dari catatan setiap anggota supeltas yang telah didokumentasikan di Kantor Satlantas Polresta Solo. Namun, anggota supeltas itu bukanlah tenaga kerja yang diperbantukan untuk Satlantas Polresta Solo, mereka itu bekerja sebagai relawan. Pihak kepolisian bahkan tidak pernah mensosialisasikan untuk menerima pembukaan perekrutan tenaga kerja sebagai pembantu pengatur lalulintas, menurut Kasat Lantas Polresta Solo menjelaskan bahwa mereka secara sadar dan tulus mendatangi Kantor kepolisian menawarkan diri atau melamar menjadi anggota supeltas. (Jaringan Informasi Bisnis Indonesia).

Kendati sebagai sukarelawan sudah barang tentu memerlukan pengetahuan tentang teknik bagaimana cara mengatur dengan baik pada masyarakat dalam keadaan yang sangat kompleks disaat di perjalanan. Dari kepolisian ternyata menyikapi tidak keberatan dan menindaklajuti melakukan pembinaan dengan memberikan pelatihan-pelatihan diantaranya baris-berbaris, tata cara mengatur arus lalulintas saat bertugas di lapangan dan aturan lainnya yang selama ini diterapkan oleh anggota satuan lalulintas. Pembinaan itu sebagai bentuk adanya kepedulian dari anggota satlantas untuk berbagi ilmu kepada siapapun yang mempunyai tujuan pengabdian termasuk supeltas.

Kepedulian dari kepolisian terhadap supeltas bukan berupa materi, namun dalam bentuk pembinaan secara intensif selama dua pekan sekali. Keberadaan sukarelawan pengatur lalulintas (supeltas) di beberapa ruas jalan di Solo memang sangat penting, serta tugas dan tanggung jawab yang menjadi beban yang harus diembannya cukup besar, tujuan 
dalam membantu tugas aparat kepolisian untuk menciptakan kondisi jalan lalulintas di Solo bisa tertib dan lancar. Mereka sangat luar biasa bahwa dalam bekerja tanpa pamrih dan menunjukkan kinerjanya benar-benar membantu kepentingan masyarakat untuk mengurai kemacetan di beberapa ruas jalan baik simpang tiga maupun perempatan jalan di luar lokasi yang belum dijaga atau diatur oleh polisi.

Di Kota Solo, awalnya supeltas dibentuk pada pertengahan tahun 2005 hanya beranggotakan tiga orang dari pembantu polisi yang ditugaskan oleh satuan lalulintas (Satlantas) Polresta Surakarta. Tugas yang diberikan adalah untuk membantu tugas polisi dalam mengatur lalulintas di Pasar Nongko dan perempatan Dawung yang ketika itu sangat padat pengendara motor dan kendaraan lainnya. Seiring dengan padatnya arus kendaraan dan kurang tertibnya pengendara motor, sehingga menimbulkan keinginan orang lain untuk menggerakkan hati rekan-rekannya, ada sebagian dari pengamen yang aktivitasnya sering nongkrong wilayah Gendengan ikut juga membantu mengurai kemacetan yang terjadi di simpang pertigaan Kalitan diantara gedung gereja, SMP Negeri 24/25 dan kantor kepolisian.

Saking macetnya jalan di sekitar pertigaan barat ndalem Kalitan, ada seorang warga ibu-ibu terlihat kesulitan untuk menyeberang jalan, waktu itu tidak ada seorangpun mencoba membantu untuk mengatasi untuk mengurai padatnya lalulintas. Keesokan harinya dan hampir setiap hari masih menjadi perhatian mantan pengamen tersebut bahwa keadaan di lokasi sekitar SMPN 24/25 masih tetap saja macet, bahkan kondisi kepadatan lalulintas sampai lampu hijau trafic light menyalapun hanya sejenak terurai dan macet kembali.

Berawal dari peristiwa yang kerap terjadi di jalan utama sekitar ruas Kota itu, Martinz merasa tergugah untuk membantu mengatasi persoalan kemacetan yang terjadi di jalan Muwardi yang ia pernah mengamen ditempat tersebut. Oleh Martinz kemudian pekerjaan ngamen akhirnya ditinggalkan hanya berkeinginan menyumbangkan tenaganya untuk berpikir ikut mengatasi persoalan kemacetan yang terjadi setiap hari di jalan raya. Sudah berjalan beberapa hari tantangan selalu dihadapinya, baik dari pengguna jalan yang tiba-tiba saat melewati ada yang memberikan saweran atau uang sekedarnya bahkan nilai rupiahnya tak seberapa itupun tidak diperbolehkan atau ditegur oleh pihak polisi yang mengetahui dan dianggap mengganggu pengendara.

Setiap harinya bahkan yang sering dijumpainya pengemudi ada yang susah diatur dan pekerja relawan jalan lalulintas itupun berusaha bersikap sabar serta hanya mampu mengingatkan. Jika pengguna jalan masih saja susah diatur tentu saja hanya dibiarkan sebab bila ada kejadian yang tidak diinginkan sudah menjadi resiko pengguna jalan itu sendiri. Sebagai orang yang dipercaya di kelompok sukarelawan pengatur lalulintas juga berfungsi sebagai pengawas sekaligus membimbing serta memberi motivasi terhadap anggotanya, secara internal para anggotanya diharuskan menerapkan fungsi-fungsinya dengan disiplin sebaik mungkin termasuk berpakaian menggunakan identitas Supeltas. Dengan pakaian seragamnya bisa membedakan mana yang benar-benar Supeltas dan mana yang bukan Supeltas, setiap anggota diharapkan harus benar-benar semangat mengabdi dan ikhlas menjadi sukarelawan jalan lalulintas, tidak diperbolehkan menjadi Supeltas musiman. 
Diterbitkan oleh Program Studi IImu Komunikasi

Universitas Ahmad Dahlan Yogyakarta

Ketika itu, personil bertambah jumlahnya muncul dari beberapa orang yang secara spontanitas sedang membantu mengatur lalulintas mendapat tanggapan atau pandangan yang miring dari pengguna jalan dengan menyebut mereka sebagai pak Ogah, karena ada yang minta uang dari pengendara yang melewati persimpangan yang dilalui. Kemudia berkembang menjadi banyaknya opini ada yang bersifat keluhan maupun sikap tidak setuju tentang kehadiran pak Ogah, sebab itu dari pihak kepolisian memanggil mereka dikumpulkan di Kantor Kepolisian Satlantas Polresta untuk diberi pembinaan. Dari hasil pembinaan tersebut selanjutnya dibentuk suatu komunitas sukarelawan, kepanjangannya dinamakan Sukarelawan Pengatur Lalulintas (Supeltas) yang berada di bawah naungan Unit Pendidikan dan Rekayasa Satlantas Polresta Surakarta.

Kepolisian sebagai aparat pemerintah mempunyai inisiatif dengan memberikan rompi berwarna hijau skotligt dan topi yang harus dikenakan setiap menjalankan tugasnya sebagai identitas untuk dikenal. Dibalik itu dalam pelaksanaan tugasnya mereka dilarang secara sengaja meminta imbalan kepada pengguna jalan. Sesuai dengan kehendak mereka pada awalnya bahwa kehadirannya harus konsisten untuk mengabdikan dirinya pada masyarakat.

Sampai dengan saat ini jumlah anggota supeltas semakin bertambah hingga jumlahnya sampai dengan 50 orang. mereka ditempatkan di 23 titik rawan kemacetan diantaranya di simpang perempatan Wora-Wari, perempatan Solo Paragon, Bundaran Baron lokasinya dekat dengan kantor polisi Baron dan sebelah selatan Stadion Sriwedari, Bundaran Purwosari, Pasar Nongko dan beberapa tempat lain yang kondisinya padat pengguna jalan. Keanggotaan supeltas berasal dari berbagai latar belakang pekerjaan sebelumnya ada yang bekerja sebagai pengemudi becak, buruh bangunan, pengamen dan sopir angkutan Kota. Kini keberadaan Supeltas semakin dibutuhkan oleh para pengguna jalan, dengan rompi hijau menyala yang menutupi kemeja warna biru lengan panjang, sepatu Dinas khas dan berbagai atribut khas Supeltas lainnya, dan mereka siap membantu kelancaran perjalanan warga di mana saja yang terdapat di Kota Solo tanpa peduli dengan teriknya panas matahari.

Keberadaan Supeltas cukup membantu masyarakat pengguna jalan lalulintas terutama di pagi hari ketika warga banyak melakukan kegiatan masuk kerja dan sore hari waktunya warga pada umumnya pulang kerja. Kota Solo setiap harinya sudah tidak dapat dipungkiri lagi bahwa selalu dihadapi kepadatan pemakai kendaraan di berbagai simpang jalan, dan bisa dipastikan muncul terjadi kemacetan, hal itu memang diuntungkan oleh Supeltas karena kontribusinya tenaga pengabdiannya. Sikap sabar ternyata dimiliki oleh para anggota Supeltas dalam mengatur lalulintas meski terik matahari menyengat dan hujanpun yang mengguyur badannya bukan menjadi halangan atas ketulusannya membantu masyarakat. Keberadaannya memang murni atas kepeduliannya terhadap lingkungan sehingga bukan semata uang yang diutamakan. Lebih mengutamakan kelancaran dan keamanan masyarakat pengguna jalan raya. 


\section{Analisa Data dan Pembahasan}

a. Motivasi Supeltas Melakukan Pekerjaan Relawan

Walaupun tidak mendapatkan gaji pokok dari pihak pemerintah ataupun kepolisian, kesadaran menjadi sukarelawan pengatur lalulintas ini dijalankan atas dasar ketulusannya untuk mengabdikan diri pada masyarakat yang seyogyanya pengguna jalan setiap saat mendapatkan pelayanan dari pemerintah daerah dengan baik. Kenyataan yang ada di lapangan, supeltas di Kota Solo ini mendapatkan penghasilan atau imbalan jerih payahnya kadangkala dari pengguna jalan. Penerimaan setiap penghasilannya tidak dapat dipastikan, hal ini sangat disadari dengan baik sebab itu sebagai pekerja relawan dengan tekad kesungguhannya telah beranggapan bahwa rejeki yang akan diterimanya itu sudah ada yang mengatur berapapun jumlahnya.

Itupun tergantung pribadi supeltas yang menjalaninya, kalau diawali dari rumah dengan semangat untuk membantu kepentingan masyarakat dengan maksud tidak punya pamrih, maka biasanya tak terduga penghasilan yang diterimanya dari masyarakat pengguna jalan cukup lumayan yang diterimanya. Sebaliknya kalau keberangkatannya untuk mengatur di jalanan diawali dengan malas-malasan dan mulai kerja sudah kesiangan tentu saja akan mendapatkan hasil yang sangat minimal banget. Hari-hari tertentu seperti hari Senin hingga Minggu tidak berpengaruh pada penghasilan yang diperoleh, walaupun hari Jum`at sampai Minggu merupakan weekend identik dengan keramaian di Kota, tapi juga tidak mempengaruhi besar kecilnya penghasilannya. Bahkan pengguna jalan yang berkendaraan mobil bagus-bagus itu ketika lewat belum tentu juga memberikan saweran atau memberikan sekedar balas jasa.

Dijelaskan oleh Theodore M.Newcomb, Ralph H.Turner dan Philip E.Converse $(1981,37)$ bahwa tingkah laku setiap individu manusia itu sudah mengalami modifikasi, artinya apa yang pernah dilakukan tentang sesuatu dari seseorang sebelumnya ada hubungannya dengan perilaku selanjutnya dalam berinteraksi dengan orang lain. Beberapa waktu kemudian bersama-sama dengan orang lain tersebut untuk melakukan aneka ragam aktivitas yang semuanya itu konsisten satu sama lainnya dengan maksud untuk mencapai tujuan tertentu. Dalam kenyataan bahwa sebagian besar dari hal-hal yang dilakukan orang tersebut sesungguhnya ikut menyumbang kearah suatu tujuan utama. Berkaitan dengan motivasi supeltas adalah tujuan yang diinginkan untuk membantu mengatasi keruwetan jalan lalulintas yang sedang dan akan terjadi.

Dengan cuaca di jalanan panas dan berusaha keras berdiri di tengah perempatan dan ada yang di sudut jalan pertigaan tanpa traffic light membantu masyarakat untuk mengurai kemacetan lalulintas, tanpa mengetahui akan mendapatkan hasil berapa rupiah jumlahnya untuk keluarga yang menunggu di rumah. Tetapi kepeduliannya terhadap situasi jalanan yang semakin padat dan ruwet, semestinya melihat keadaan di lapangan dalam kondisi demikian makin menumbuhkan kesadaran para polantas yang memang berhak dan wajib untuk menertibkan jalan raya. Saat melakukan pekerjaan sebagai relawan ini tidak sekedar menggerakkan tangan atau meniup peluit, tapi juga memberikan tanda-tanda khusus kapan harus memerintahkan pemakai kendaraan untuk melaju, berhenti atau kendaraan dari sebelah mana yang harus melaju lebih dulu. 
Diterbitkan oleh Program Studi IImu Komunikasi Universitas Ahmad Dahlan Yogyakarta

\section{b. Kredibilitas Supeltas Selaku Komunikator}

Bukankah petugas aparat pemerintah dalam menjalankan pekerjaan penjaga, pengawas dan pengatur lancarnya perjalanan pengendara bermotor telah mendapatkan kesejahteraan tetap dan lebih mampu dalam menunjang kehidupannya dibandingkan dengan supeltas. Setidaknya polantas dan aparat pemerintah yang terkait mempunyai pengetahuan dan menguasai tentang perundang-undangan lalulintas, seharusnya sangat peduli dan bisa memberikan contoh yang nyata atas tanggungjawabnya kepada masyarakat pada umunya. Bukan berarti dengan adanya supeltas lalu dianggapnya meringankan beban tugas dengan mengurangi aktivitasnya rutin terjun langsung ke lokasi dimana setiap harinya rawan kemacetan. Menurut informasi dari beberapa pengguna jalan raya bahwa sosok supeltas di jalan raya dengan sikap kerendahan hatinya dan penuh semangat itu, sementara ini kehadirannya cukup disegani ketika sedang melakukan aktivitasnya ditengah-tengah masyarakat.

Pengetahuan merupakan sumber kekuatan, dengan mengetahui mekanisme komunikasi seperti ketika menyampaikan pesan kepada orang lain, sebelumnya sudah berpikir cara mengantisipasi, menduga lebih dulu bagaimana orang lain tadi akan menerima, mengolah, dan menyimpan informasi yang akan disampaikan. Memiliki pengetahuan yang luas dapat dipergunakan untuk menciptakan hubungan diantara kita lebih efektif, lebih memuaskan dan lebih menyenangkan bagi orang banyak. (Jalaludin Rakhmat, 2007: 259)

Menurut pendapat sebagian warga Solo, pihak aparat kepolisian sebenarnya berupaya memberikan atau menciptakan image yang baik, membangun citra atas kewajibannya sebagai pengayom dan melindungi keamanan bagi pengguna jalan raya. Sehingga kekecewaan masyarakat dari sedikit terobati jika aktivitas aparat kepolisian menunjukkan sentuhan rasa manusiawinya. Dengan adanya keterbukaan, supaya tidak membuat warga merasa takut dan justru sebaliknya diantara warga masyarakat pengguna jalan saling menghargai dan membantu untuk kerjasama dengan pihak berwajib menertibkan keadaan lalulintas yang semakin padat.

Supeltas ditengah kepadatan dan keruwetan jalan lalulintas semakin dirasakan oleh masyarakat sangat membantu dan sudah dibutuhkan. Ternyata supeltas mempunyai kemampuan dalam memberikan cerminan bagi setiap pengguna jalan bersikap sabar dan mau mentaati kehendak supeltas dengan cara penyampaian pesan bahasa tubuh. Sudah cukup banyak masyarakat yang memberikan kesan positif dan ada juga yang memberikan kesan negative. Akan tetapi terbukti tidak mengurangi semangat para relawan jalan lalulintas, untuk terus melakukan pekerjaannya sebagai relawan dengan tulus dan senang hati.

\section{c. Efektivitas Komunikasi Nonverbal Supeltas}

Peralatan yang dipergunakan oleh supeltas dalam bahasa tubuh adalah hati nurani, akal pikiran, budi dan naluri, bekerja sepanjang kesadaran supeltas sebagai pemiliknya. Motif komunikasi yang mendorong supeltas melakukan tindak komunikasi dengan menyampaikan pesan nonverbal. Pesan nonverbal diartikan disini oleh supeltas dengan gerak gerik, mimik, serta suara alat peluit untuk menyampaikan apa ia pikir dan rasakan. Jadi, pesan yang disampaikan berupa nonverbal itu adalah pemikiran dan perasaan supeltas 
dalam mengekspresikan diri agar orang lain memahaminya. Pesan pada dasarnya bersifat abstrak, untuk membuatnya konkrit manusia dengan akal budinya menciptakan lambang komunikasi seperti gerak-gerik yang dilakukan para supeltas dan bahasa lesan maupun bahasa tulisan.

Menurut persepsi warga Solo, salah seorang dari mereka pernah membuktikan sendiri dan pernah juga dibantu oleh supeltas berseragam, dan kebetulan dalam keadaan cuaca sangat panas beradu dengan debu dan asap jalanan yang larut dalam udara. Kemudian dari salah seorang pengguna jalan telah mengakui juga bahwa petunjuk atau perintah supeltas ketika mengatur di tengah pertigaan dan perempatan yang belum terpasang traffic light sangat membantu dan efektif, karena terlihat dengan jelas pesan nonverbal oleh supeltas telah dipatuhi oleh pengguna jalan yang dilewati tersebut. Bahkan ada yang mengatakan dari beberapa pengemudi mobil pribadi bahwa dirinya merasa sering terbantu oleh teknik yang digunakan oleh supeltas dalam perjalanannya saat melalui keruwetan di persimpangan jalan yang tidak ada tanda lampu bangjonya.

Lambang komunikasi bisa diartikan sebagai kode atau simbol, tanda lain yang digunakan komunikator untuk mengubah pesan yang abstrak menjadi konkrit. Sering terjadi, komunikan tidak akan mengerti apa yang dipikirkan dan dirasakan komunikator sampai pada mewujudkan pesan ke dalam salah satu bentuk lambang komunikasi atau pesan yang bersifat nonverbal (Dani Vardiansyah, 2004:61). Manusia membuat simbol dan memberi makna atas simbol tersebut untuk merujuk pada obyek atau gagasan tertentu. Tanpa adanya kemampuan mewujudkan pesan dalam bentuk lambang komunikasi, maka hanya tinggal gagasan yang berada dalam benak komunikator.

Di tempat kerumunan non formal oleh beberapa warga juga pernah ada perbincangan yang sifatnya spontanitas telah menyinggung tentang relawan lalulintas ternyata mereka berpendapat bahwa sangat mengapresiasi kontribusinya dalam mengurai kemacetan lalulintas. Di sisi lain, banyak sekali warga kebetulan merasa terbantu kelancaranya di jalan sehingga menunjukan sikap menghargai dengan sangat relative memberikan imbalan. Lebih menarik lagi, menurut warga bahwa supeltas dengan penampilan yang ditunjukan dihadapan pengguna jalan sangat bervariatif, sopan dan lucu, sehingga pesan nonverbalnya sangat persuasive.

Hidup untuk memberkahi orang lain dan berjuang tidak hanya untuk dirinya sendiri, selalu merelakan apa yang dipunyai untuk orang lain. Persimpangan jalan bukanlah satu-satunya titik yang sering dijaga supeltas, tapi ada supeltas yang menjaga tempat yang biasa diperuntukkan bagi masyarakat yang ingin memutar haluan untuk berbalik arah. Kegiatan yang dilakukan para supeltas membutuhkan pengetahuan untuk mempersiapkan mental dirinya bukan karena faktor keterpaksaan, tapi harus mampu berinteraksi dengan baik. Dalam kenyataannya pekerja relawan tersebut telah berusaha dengan cara-cara yang dimiliki sesuai karakteristiknya mampu mempengaruhi pengguna jalan, teknik yang dipergunakan menunjukkan gaya gerak-gerik cukup menarik perhatian dan komunikatif.

Oleh sebab itu, bahwa komunikasi melalui pesan nonverbal atau gerakan bahasa tubuh dapat dikatakan komunikasi berlangsung efektif, mengingat keberadaan supeltas sampai sekarang sangat dibutuhkan warga Kota Solo. 
Diterbitkan oleh Program Studi IImu Komunikasi

Universitas Ahmad Dahlan Yogyakarta

\section{Penutup}

Dengan kondisi di jalan yang padat dan ruwet semua resiko yang mungkin terjadi dan akan terjadi tersebut, keberadaan pekerja relawan ternyata membuat suasana di lokasi jalan macet menjadi lebih teratur, sehingga pekerja supeltas memberikan kontribusi mampu ikut mengatasi persoalan di jalan raya. Petugas relawan ini memang mulai mendapat perhatian dan bimbingan dari pihak kepolisian, agar menjadikan mereka piawai membantu ketertiban di beberapa ruas jalan lalulintas hingga lancar. Harapan para pekerja relawan tanpa pamrih di jalan raya kota Solo, jika diberi karunia semoga dirinya mendapatkan perhatian dan menjadi pertimbangan bagi pemerintah, bahwa kehadirannya dalam kesertaannya mengabdikan pada masyarakat bisa menjadi medium kerjasama dalam mengatasi kepadatan di jalan, serta lebih dimungkinkan menjadi contoh atau bahkan pelopor bagi masyarakat sekelilingnya.

Supeltas merasakan ada pengakuan dengan menyumbangkan tenaganya menjadi relawan secara tidak langsung mendapat dukungan rasa aman dan akan tetap kerja melayani masyarakat di jalanan sampai kapanpun, yang terpenting organisasi supeltas tetap langgeng, kompak, dedikatif dan semangat. Seminimal mungkin kepemilikan pengetahuannya supeltas menentukan keberhasilan komunikasi, karena pesan nonverbalnya mampu menggerakkan dan mengatur pengguna jalan raya. Asumsi pengguna jalan mengatakan bahwa sumbangsih relawan dapat disimpulkan tulus, dapat dipercaya dan perilakunya dapat diandalkan untuk memberikan kontribusi aparat pemerintah dalam ikutserta menyelesaikan keruwetan lalulintas di Kota Solo.

\section{Daftar Pustaka}

Ahmadi, Abu, 1991, Psikologi Sosial, Jakarta, Rinaka.

Cangara, H. 1998, Pengantar Ilmu Komunikasi, Jakara, Raja Grafindo Persada.

Gerungan, WA, 1977, Psikologi Sosial Bandung-Jakarta, Eresco.

Hamidi, 2010, Metodelogi Penelitian dan Teori Komunikasi, Malang, UMM Press.

Hardjana M.Agus, 2003, Komunikasi Intrapersonal dan Interpersonal, Yogyakarta Kanisius.

Hendra Negoro, Sherly, 2014, Kredibilitas Customer Service dan Citra Perusahaan, Yogyakarta, Universitas Atmajaya.

Newcom, Turner, 1981, Psikologi Sosial, Bandung, Diponegoro.

Rahkmat, Jalalludin, 1989, Metode Penelitian Komunikasi, Bandung, Remaja Karya. 2007, Psikologi Komunikasi, Bandung, Remaja Rosdakarya.

Sutopo HB, 2006, Metodologi Penelitian Kualitatif, Surakarta, Universitas Sebelas Maret. 
Sindoro, Alexandra, 1996, Komunikasi dan Negosiasi, Jakarta, Prenhallindo.

Sarlito W.Wirawan, 2013, Pengantar Psikologi Umum, Jakarta, Raja Grafindo Persada. Soemirat, S. dan Ardianto, E, 2010, Dasar-Dasar Publik Relations, Bandung, Remaja Rosdakarya

Sawitri S. Sadarjoen, 2015, Bahasa Tubuh Dan Pengambilan Keputusan, Jakarta, Kompas.

Vardiansyah, Dani, 2004, Pengantar Ilmu Komunikasi, Bojongkerta, Ghalia Indonesia. 